\title{
Effect Of Lysine On Growth Development Of Chicks By Supplying Food Prepared From Locally Available By Products.
}

\author{
${ }^{1}$ A. Nargis and ${ }^{2}$ D. Talukder \\ BCSIR Laboratories, Binodpur Bazar, Rajshahi- 6206.
}

\begin{abstract}
Deficit of high quality animal feed is an important obstacle for raising poultry farm. So, a mixture of animal and vegetable protein mixed with vitamin (lysine) which is an enriched feed for chicks. The percentage of proteins, fat. fiber, ash, and moisture were $28.35 \%, 3.78 \%, 9.33 \%, 18.06 \%$ and $11 \%$ in our prepared feed, where $19 \%, 6 \%, 5 \%, 8 \%$ and $13 \%$ in market's food. The chicks gain weight after 90,135 and 180 days were $3.43 .89 \pm 8.93,557.44 \pm 13.27$ and $673.5 \pm 9.87$ by supplied our own product where as $287.00 \pm$ $16.00,519.88 \pm 15.43$ and $631.16 \pm 5.44$ were in chicks by supplied market's food. DGC (Daily growth coefficient), SGR ( Specific growth rate), PCR (Food conversion ratio) and SGI (specific growth index) were 2.44, 244.44, 40.09 and 0.613 in chicks supplied by our own food whereas the parameters were 2.16, 216.66, 53.96 and 0.969 in chicks supplied by the market's food respectively.

Key Wards: Chickens, shrimp shell, antibiotics, balanced and nutrient diets
\end{abstract}

\section{Introduction}

Poultry farming plays an important part in the rural economy and providing a ready and additional source of income to the farmers. Feed, is the most expenditure item and the cost of feed represents than half of the total expenditure on raising poultry. So, care is needed in selecting a mixture of animal and vegetable proteins food for egg production.

In our country, deficit of high quality of animal feed exists. A huge quantity of shrimp shells are carelessly dropped else where from different fish processing plants and Chinese Restaurants especially in the Southern districts of Bangladesh. This shrimp shells are sources of protein, calcium, phosphorus and minerals. The aim of this research work is to prepare protein, vitamin, mineral enriched poultry feed from indigenous and available sources like shrimp shell.

This prepared poultry feed is cheap and available locally. This balanced feed is one, which contains nutrients in proper proportions. Chickens needs to eat a balanced, nutrients rich diet so they can experience optimal growth, weight gain, egg production and immunity from various poultry disease (Quentin et al., 2005).

Modern livestock production systems use antibiotics and other antimicrobials to present or treat diseases in animals. These antibiotics improved weight gain and feed utilization in broiler chickens and turkeys, pigs, calves, beef, cattle and replacement dairy heifers. (Kim. 2005).

\section{Materials And Methods}

Freshly collected shrimp shells (100gm) were washed, sundried and thoroughly grounded in blender, produced 400gm powder. Powder obtained from shrimp shells was sieved through a 35-mesh sieve. Then mustard cake $(200 \mathrm{~g})$, rice bran $(150 \mathrm{~g})$, wheat bran $(200 \mathrm{~g})$ common salt $(25 \mathrm{~g})$, crushed oyster shell $(25 \mathrm{~g})$ and vitamin (Lysine 0.0000005) were admixed together with the powder and finally grounded well. It produces $1000 \mathrm{~g}$ or $1 \mathrm{~kg}$ enriched poultry feed. A comparative trial was made on 14 chickens from starting the supplying of prepared own food and market food up to 180days. Weight of the hens was taken after 45 days interval. The prepared food $(300 \mathrm{gm})$ were moistened with some water then supplied to each hen thrice time daily.

Protein level $(\mathrm{N} \times 6.25)$ was determined by the Kjeldahl method after an acid digestion using an Auto Kjeldahl system (1030* Auto analyzer, tecator, Hoganos, Sweden). Fat level was determined by the ether extraction method by Soxtec system HT (Soxtec system $\mathrm{HT}_{6}$, Tecator, Hoganos, Sweden). Moisture and ash were analyzed after AOAC method.

\section{Results And Discissions}

Table-1 shows the comparative study of the prepared food and other poultry feed available in market. It shows that prepared food is more rich then the food from market. The protein and fiber percentage of our prepared food are $28.95 \%$ and $9.33 \%$ whereas the percentage of protein and fiber are $19 \%$ and $5 \%$ in market food. The fat percentage is greater in market food (6\%) then the prepared food (3.78\%).

Table-2 shows proximate composition of different feed ingredients used in prepared our own poultry feed. The protein percentage of mustard cake is highest (27.46\%) then rice bran (12.3\%), wheat bran (10.09\%) and oyster shell $(1.86 \%)$. The percentage of crude fiber of mustard cake is also highest $(10.09 \%)$ then other 
ingredients. Table- 3 shows comparative trial report between supplied own product and supplied from market product. The mean of the weight of the chicks which feed on our supplied own food were $343.89 \pm 8.93$ (after 90 days), $557.44 \pm 13.27$ (after135days) and $673.5 \pm 9.87$ (after 180 days) whereas the total mean and weight of the chicks which feed on market food were $287 \pm 16$ (after 90days), 519.88 \pm 15.43 (after 135days) and $631.16 \pm 5.44$ (after 180 days). The results obtained from supplied own food after 90, 135 and 180 days are highly significant at $0.05 \%$ and $0.001 \%$ level of t-test. Table- 4 shows the weight gain of chicks by supplied own prepared food is $(440 \mathrm{gm})$ and $(390 \mathrm{gm})$ in chicks by supplied the market food. The daily growth co-efficient (DGC), specific growth rate per day (SGR) and food conversion ratio (FCR) were 2.44, 244.44 and 40.09 in trial - A i.e. our prepared food and 2.16, 216.66 and 53.96 in trial - B i.e. on market food. The specific growth index (SGI) in prepared food was 0.61 and 0.96 in market food. The use of lysine (antibiotic) in our prepared own food effects the food rich and healthy and for growth improvement. Quentin et al (2005), Patience (1990), Lehmann et al (1996), Han et al (1994), Rezaei (2004) and Prescott et al (2000) used lysine and found good results i.e. lysine level increases live performance and breast yield in male broiler. Morris et al (1987), Kidd et al (1998), Kerr et al (1999) and Garu (1984) also works on lysine which effect protein concentration on response to dietary lysine by chicks.

\section{Conclution}

It is concluded that the prepared food is a rich, balanced feed for chicks than other markets' food which can easily prepared from by products available in our country where shrimp shell act as a source of animal protein, mustard cake as vegetable protein, rice bran, wheat bran are as food grain, oyster shells serve as calcium supplement, vitamin and common salt are as minerals.

\section{Acknowledgment}

The authors express their gratitude to Mr. Md. Mozzamel Hoque, Director, BCSIR Laboratories, Rajshahi for providing all research facilities.The authors also express their sincere thanks to Chairman , BCSIR Dhaka for his kind co-operation

\section{References:}

[1] Han, Y. and D.H. Baker 1994. Digestive lysine requirement of male and female broiler chicks during the period three to six weeks post hatching. Poultry Sci. 77: 864-869.

[2] Kidd, M. T., B. J. Lerr, K. M. Halpan, G. W. Mcward and C. L. Quarles, 1998. Lysine levels in starter-finisher diets affects broiler performance and carcass traits. J.Appl.Poult.Res. 7: 351-358.

[3] Garu, C. R. 1984 . Effect of protein level on the lysine requirement of the chicks. J. Nutr., 36: 99-108.

[4] Association of Official Analytical Chemists (AOAC) (1990).Official methods of Analysis of the AOAC (W. Hotwithz Ed), (13 ${ }^{\text {th }}$ Edn).

[5] Kim Klotins 2005.Antibiotic use for growth improvement controversy and resolution. FACTSHEET .

[6] Kerr ,B. J. ,M. T. Kidd, K .M. Halpan, G. W. Mcward and C. L. Quarles 1999. Lysine level increases live performance and breast yield in male broiler. J. Appl. Poult. Res., 8 : 381-390.

[7] Lehmann, D. M. Pack and H. Jeroch, 1996. Responses of growing and finishing turkey toms to dietary lysine. Poultry Sci. 75 : 711-718.

[8] Morris,T.R.,K.Alazzawi,R.M.Gous and G. L. Simpson 1987. Effect of protein concentration on response to diatary lysine by chicks.Br.Poult.Sci., 28: 185-195.

[9] Maxime Quentin, Isabelle Bouvarel and Michel Picard 2005.Effects of crude protein and lysine contents of the diet on growth and body composition of slow-growing commercial broilers from 42 to 77 days of age. Anim.Res .54. 113-122.

[10] Patience, J.F 1990. Potential for the use of antibiotics and probiotics as growth promotors. Proceedings of the Banff Pork Seminar. Vol.1, Faculty of Extension, University of Alberta ,PP 29 . 44.

[11] Prescott, J. F., J.D.Baggot,R.D.Walker. Antimicroboal Therapy in Veterinary Medicine , $3^{\text {rd }}$ ed. Iowa State University Press,Ames,Iowa p.3.

[12] Rezaei, M. H. Nassiri Moghaddam, J. Pour Reza and H. Kermanshahi. 2004 .The effect of dietary protein and lysine levels on Broiler Performance, Carcass characteristics and N excretion. International Journal of Poultry Science 3 (2): 148-152. 
Table -1. Comparative study of the own prepared food and other poultry feed available in market.

\begin{tabular}{|l|c|c|}
\hline Name of the parameters & $\begin{array}{c}\text { Chemical composition of our } \\
\text { prepared poultry feed }\end{array}$ & $\begin{array}{c}\text { Chemical composition of } \\
\text { poultry feed available in } \\
\text { market. }\end{array}$ \\
\hline Protein (\%) & 28.95 & 19 \\
\hline Fat (\%) & 3.78 & 6 \\
\hline Fibre (\%) & 9.33 & 5 \\
\hline Ash (\%) & 18.06 & 8 \\
\hline Moisture (\%) & 11 & 13 \\
\hline
\end{tabular}

Table -2. Proximate composition of different feed ingredients.

\begin{tabular}{|l|l|c|c|c|c|}
\hline No. & Feed ingredients & $\begin{array}{c}\text { Protein } \\
(\%)\end{array}$ & Dry matter (\%) & Total ash (\%) & Crude fibre (\%) \\
\hline 1. & Mustard cake & 27.46 & 86.72 & 7.13 & 10.09 \\
\hline 2. & Rice bran & 12.3 & 87.5 & 13.38 & 12.61 \\
\hline 3. & Wheat bran & 10.09 & 81.15 & 5.18 & 9.51 \\
\hline 4. & Oyster shell & 1.86 & 97.17 & 86.03 & - \\
\hline
\end{tabular}

Table-3. Comparative trial report between supplied own product and supplied market product.

\begin{tabular}{|l|c|c|}
\hline & Supplied own product & Supplied market product \\
\hline Initial wt. of the Chicks & 250 & 250 \\
\hline After 90 days & $343.89 \pm 8.93$ & $287 \pm 16$ \\
\hline After 135 days & $557.44 \pm 13.27$ & $519.88 \pm 15.43$ \\
\hline After 180 days & $673.5 \pm 9.87$ & $631.16 \pm 5.44$ \\
\hline
\end{tabular}

Table- 4. Daily growth co-efficient (DGC), Specific growth rate (SGR), Food conversion ratio (FCR) and Specific growth index (SGI) of chikens under two diet.

\begin{tabular}{|l|c|c|}
\hline Parameters & A & B \\
\hline Initial wt. (gm.) & 250 & 250 \\
\hline Final wt. (gm.) & 690 & 640 \\
\hline Weight gain (gm.) & 440 & 390 \\
\hline Weight gain (\%) & 176 & 156 \\
\hline Daily growth co-efficient (DGC) & 2.44 & 2.16 \\
\hline Specific growth rate (SGR) & 244.44 & 216.66 \\
\hline Food conversion ratio(FCR) & 40.09 & 53.96 \\
\hline Specific growth index (SGI) & 0.61 & 0.96 \\
\hline
\end{tabular}

